E-JURNAL EKONOMI DAN BISNIS UNIVERSITAS UDAYANA
Available online at https://ojs.unud.ac.id/index.php/EEB/index
Vol. 11 No. 01, Januari 2022, pages: $59-70$
e-ISSN: $2337-3067$

\title{
PENGARUH CR DAN DER TERHADAP ROA PADA PT. SELAMAT SEMPURNA
} Tbk PERIODE 2010-2019

\section{Sella Putri Anisa ${ }^{1}$ Aria Aji Priyanto ${ }^{2}$}

Article history:

Submitted: 22 Juli 2021

Revised: 8 Agustus 2021

Accepted: 15 September 2021

\section{Keywords:}

Current Ratio $(C R)$; Debt to Equity Ratio(DER); Return On Asset (ROA).

\section{Kata Kunci:}

Current Ratio $(C R)$;

Debt to Equity Ratio(DER); Return On Asset (ROA).

\section{Koresponding:}

Universitas Pamulang Tangerang Selatan, Banten, Indonesia

Email:

sellaputrianisa@gmail.com

\section{Abstract}

This research is in order to determine the influence of current ratio and debt to equity ratio on return on assets in the parts industry, namely PT. Selamat Sempurna Tbk period 2010-2019. The methods used in re search are descriptively associative with quantitative approaches. The population in this study used the financial statements of PT. Selamat Semp urna Tbk. Sample balance sheetreport and PT profitandloss statement. The data analysis techniques used are financial ratio analysis, descriptive statistic al analysis, statistical analysis through SPSS calculation stages u sing IBM SPSS version 25 (classic assumption test: normality test, mult ic oline arity test, heteroskedastisity test, autocorrelation test), simple linear re g ression test, multiple linear regression test, determination coefficient test and hypothesis test (t partialtest and $F$ simultaneous test). The results of this study showed that the Current Ratio(CR) andDebt to EquityRatio (DER) simultaneously have a significant effecton Return On Asset (ROA) in PT. Selamat Sempurna Tbk. Partially available from the results of the test that shows that the Current Ratio (CR) has a significant effect on Return On Asset (ROA) and Debt to Equity Ratio(DER) partially significantly affects Return On Asset (ROA).

\begin{tabular}{|c|}
\hline Abstrak \\
\hline 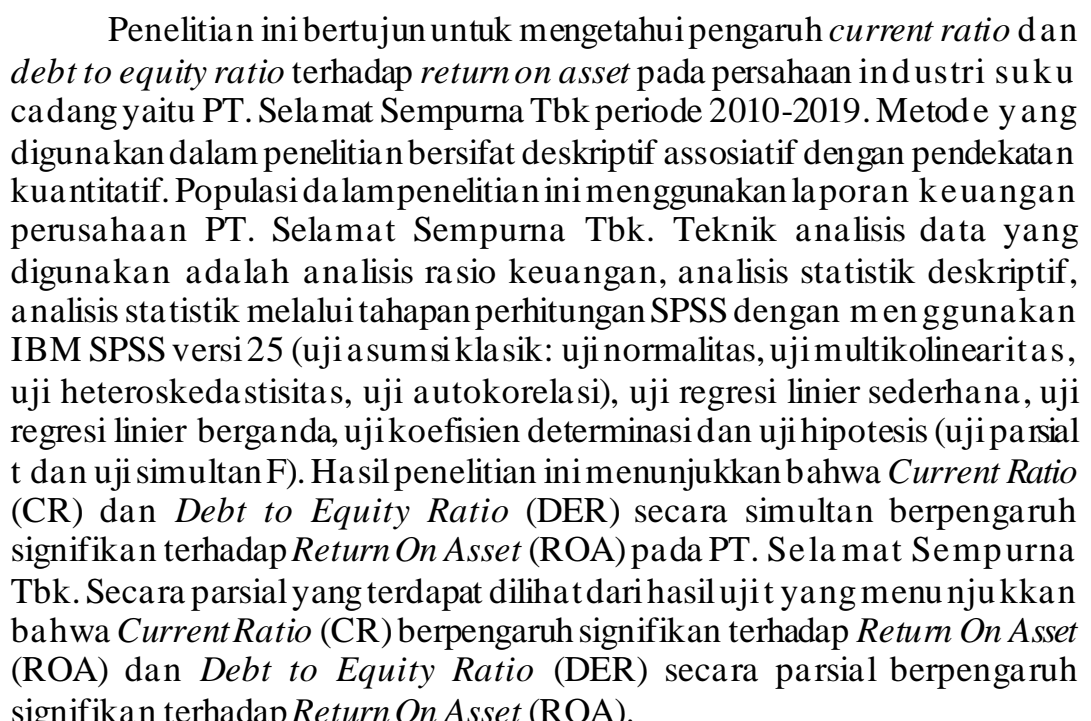 \\
\hline
\end{tabular}

Universita s Pamulang, Tangerang Sela tan, Banten, Indonesia ${ }^{2}$

Email: dosen01048@unpam.ac.id ${ }^{2}$ 
PENDAHULUAN

Perusahaan yang beroperasi dagang suku cadang merupakan aset yang berperan penting bagi pengguna mesin untuk menjaga keselamatan. Karena jika terjadi kegagalan maka dapat berakibat fatal seperti kecelakaan bagi penggunanya. Dalam dunia usaha selalu menuntut perusahaan industri suku cadang harus menghasilkan produk dengan kualitas yang terjamin. Perusahaan industri suku cadang alat-alat mesin pabrik dan kendaraan adalah salah satu industri pendukung utama sektor otomotif. Oleh karena itu perubahan kecil yang terjadi pada industri otomotif maka akan memberikan dampak yang besar terhadap perkembangan industri suku cadang.

Setiap perusahaan selalu mengupayakan tingkat keuntungan yang semakin baik, begitu pula yang dilakukan oleh perusahaan yang bergerak dibidang industri alat-alat mesin kendaraan (suku cadang). Rasio keuangan menggambarkan kekuatan dan kelemahan kinerja keuangan pada suatu perusahaan. Oleh karena itu untuk mengetahui keuntungan atau laba perusahaan maka diperlukan adanya analisis rasio keuangan agar perusahaan dapat mengetahui gambaran posisi keuangan dari perusahaan tersebut. Laporan keuangan dapat membantu berbagai pihak dalam mempertimbangkan pengambilan keputusan dalam hal keuangan. Keuntungan yang diperoleh merupakan suatu gambaran kondisi keuangan perusahaan dan laba yang dihasilkan perusahaan dapat diketahui melalui analisis keuangan.

Rasio keuangan memiliki pengaruh terhadap profitabilits dari suatu perusahaan yang tentun ya akan menjadi pertimbangan utama bagi para investor untuk menanamkan dana ke suatu perusahaan. Tujuan utama investor dalam menanamkan dana diperusahaan adalah untuk mendapatkan keuntungan atau tingkat pengembalian investasi. Investor mengharapkan laba yang diperoleh perusahaan dapat dikelola baik oleh manajer secara tetap demi kepuasan investor dan kelangsungan perusahaan. Salah satu komponen yang berhubungan dengan kondisi internal perusahaan adalah kinerja perusahaan yang terdiri dari Current Ratio (CR). Debt to Equity Ratio (DER), dan Return On Asset (ROA).

Menurut Kasmir (2014:134) "Current Ratio (CR) merupakan rasio untuk mengukur kemampuan perusahaan membayar kewajiban jangka pendek atau utang yang segera jatuh tempo pada saat ditagih secara keseluruhan". Dengan kata lain, seberapa banyak aktiva lancar yang tersedia untuk menutupi kewajiban jangka pendek yang segera jatuh tempo. Rasio lancar dapat pula dikatakan sebagai bentuk untuk mengukur tingkat keamanan (margin of safety) suatu perusahaan. Debt to Equity Ratio (DER) merupakan salah satu rasio keuangan, dimana rasio ini dapat melunasi semua utang jangka panjang maupun jangka pendek. Semakin besar rasio ini maka akan semakin tidak menguntungkan karena akan semakin besar resiko yang ditanggung atas kegagalan yang mungkin terjadi pada perusahaan.

Didirikannya suatu perusahaan mempunyai maksud dan tujuan tertentu, salah satunya yaitu untuk memperoleh laba (profit). Daya tarik bagi investor dalam suatu perusahaan yaitu memiliki profitabilitas yang tinggi. Tingkat profitabilitas yang konsisten akan menjadi tolak ukur bagaimana cara perusahaan mampu bertahan dalam suatu bisnisnya. Oleh karena itu maka wajar apabila profitabilitas akan menjadi perhatian utama seorang investor. Seorang investor pasti akan mengaitkan tingkat profitabilitas suatu perusahaan dengan tingkat risiko yang muncul dari investasinya. Salah satu rasio keuangan untuk mengukur profiabilitas adalah Return On Asset (ROA). Return On Asset (ROA) adalah rasio yang menilai sejauh mana perusahaan dalam menghasilkan laba atas seluruh asset yang dimiliki oleh perusahaan sehingga mampu memberikan pengembalian keuntungan sesuai target yang dicapai.

Berdasarkan laporan tahunan yang telah dipublikasikan oleh PT. Selamat Sempurna Tbk, maka hasil yang dicapai setiap tahunnya selalu mengalami perubahan. Perubahan tersebut menunjukan 
peningkatan maupun penurunan. Banyak indikator rasio keuangan yang dapat digunakan untuk mengukur kinerja keuangan suatu perusahaan. Tetapi, yang akan diuji dalam penelitian ini adalah rasio likuiditas dan solvabilitas yaitu Current Ratio (CR) dan Debt to Equity Ratio (DER), sedan gkan untuk rasio profitabilitas yaitu Return On Asset (ROA). Berikut ini adalah ringkasan data perbandingan berdasarkan laporan ikhtisar data keuangan yang telah dipublikasikan oleh PT. Selamat Sempurna Tbk dari tahun 2010 sampai dengan tahun 2019 yaitu sebagai berikut:

Tabel 1.

Data Laporan Keuangan PT. Selamat Sempurna Tbk. Periode 2010 - 2019

\begin{tabular}{cccc}
\hline Tahun & CR & DER & ROA \\
\hline 2010 & $217 \%$ & $96 \%$ & $14 \%$ \\
2011 & $272 \%$ & $70 \%$ & $19 \%$ \\
2012 & $194 \%$ & $76 \%$ & $19 \%$ \\
2013 & $210 \%$ & $69 \%$ & $20 \%$ \\
2014 & $211 \%$ & $53 \%$ & $24 \%$ \\
2015 & $239 \%$ & $54 \%$ & $21 \%$ \\
2016 & $286 \%$ & $43 \%$ & $22 \%$ \\
2017 & $374 \%$ & $34 \%$ & $23 \%$ \\
2018 & $394 \%$ & $30 \%$ & $23 \%$ \\
2019 & $464 \%$ & $27 \%$ & $21 \%$ \\
\hline
\end{tabular}

Sumber: Laporan Keuangan PT. Sela mat Sempurna Tbk (telah diolah), 2021

Berdasarkan Tabel 1 diatas dapat dinilai sementara pengaruh variabel-variabel independen tersebut terhadap Return On Asset (ROA). Penilaian sementara ini untuk mengetahui konsistensi Pengaruh Current Ratio (CR) dan Debt To Equity Ratio (DER) terhadap Return On Asset (ROA).

Berdasarkan tabel diatas, dapat dilihat bahwa perkembangan Current Ratio (CR) pada PT. Selamat Sempurna Tbk Periode 2010-2019 mengalami fluktuasi disetiap tahunnya. Pada tahun 2010 sebesar $217 \%$ lalu mengalami kenaikan pada tahun 2011 sebesar $272 \%$. Kemudian mengalami penurunan pada tahun 2012 sebesar $194 \%$. Setelah itu terus mengalami peningkatan pada tahun 2013 sampai 2019, dimana tahun 2013 sebesar $210 \%$, tahun 2014 sebesar $211 \%$, tahun 2015 sebesar $239 \%$, tahun 2016 sebesar $286 \%$, tahun 2017 sebesar $374 \%$, tahun 2018 sebesar $394 \%$, dan tahun 2019 sebesar $464 \%$. Jika nilai CR semakin tinggi maka perusahaan dapat memanfaatkan aktiva untuk menghasilkan laba bersih setelah pajak. Yang artinya perusahaan mampu untuk memenuhi kewajiban hutang yang akan segera jatuh tempo.

Pada rata-rata Debt to Equity Ratio (DER) juga mengalami fluktuasi setiap tahunnya. Pada tahun 2010 sebesar $96 \%$ kemudian mengalami penurunan pada tahun 2011 sebesar $70 \%$. Kemudian mengalami peningkatan pada tahun 2012 sebesar $76 \%$. Setelah itu mengalami penurunan kembali pada tahun 2013 dan 2014 sebesar $69 \%$ dan $53 \%$. Pada tahun 2015 mengalami peningkatan sebesar $54 \%$. Setelah itu terus mengalami penurunan pada tahun 2016 sampai tahun 2019, dimana tahun 2016 sebesar $43 \%$, tahun 2017 sebesar $34 \%$, tahun 2018 sebesar $30 \%$, dan tahun 2019 sebesar $27 \%$. Jika nilai DER semakin kecil maka menunjukan komposisi total hutang yang semakin rendah, hal ini akan berdampak semakin kecil beban perusahaan terhadap kreditur. Selain itu besar atau kecilnya beban hutang yang ditanggung perusahaan dapat mempengaruhi jumlah laba yang diterima oleh perusahaan. Sehingga semakin kecil resiko yang ditanggung dan semakin kecil juga kegagalan yang mungkin terjadi pada perusahaan.

Berdasarkan tabel diatas Return On Asset (ROA) pada PT. Selamat Sempurna Tbk Periode 2010-2019 mengalami fluktuasi setiap tahunnya. Pada tahun 2010 sebesar $14 \%$ meningkat pada tahun 2011 sebesar 19\%. Pada tahun 2012 mengalami penurunan sebesar $19 \%$. Setelah itu meningkat pada 
tahun 2013 dan 2014 masing-masing sebesar $20 \%$ dan $24 \%$. Pada tahun 2015 mengalami penurunan sebesar $21 \%$. Setelah itu kembali meningkat pada tahun 2016 dan 2017 masing-masing sebesar $22 \%$ dan $23 \%$. Kemudian mengalami penurunan pada tahun 2018 dan 2019 masing-masing sebesar $23 \%$ dan $21 \%$. Jika semakin tinggi nilai ROA maka laba yang diperoleh perusahaan akan semakin meningkat yang artinya perusahaan mendapatkan keuntungan yang besar pula,

Research gap dalam penelitian ini diketahui dari hasil penelitian terdahulu terdapat beberapa variabel yang mungkin berpengaruh terhadap Return On Asset (ROA) seperti penelitiannya Puput Apriyanti (2019) yang berjudul pengaruh Current Ratio (CR) dan Debt to Equity Ratio (DER) terhadap Return On Asset (ROA) pada PT. Supreme Cable Manufakturing dan Commerce Tbk, tahun 2006-2017 dengan hasil terdapat pengaruh positif dan signifikan antara variabel CR terhadap ROA dan dengan hasil terdapat pengaruh negatif dan signifikan antara variabel DER terhadap ROA. Kemudian sama dengan penelitian Ni Kadek Venimas Citra Dewi, Wayan Cipta, I ketut Kirya (2015) yang berjudul pengaruh Loan to Deposit Ratio (LDR), Loan to Asset Ratio (LAR), Debt to Equity Ratio (DER) dan Current Ratio (CR) terhadap Return On Asset (ROA) pada perusahaan perbankan yang terdapat di Bursa Efek Indonesia periode 2011-2013 dengan hasil terdapat pengaruh secara simultan dari LDR, LAR, DER, dan CR terhadap ROA. Sedangkan secara parsial terdapat pengaruh positif dan signifikan terhadap ROA dan juga secara parsial terdapat pengaruh negatif dan signifikan dari variabel DER terhadap ROA.

Berbeda dengan penelitian Herman Supardi (2016) yang berjudul Current Ratio (CR), Debt to Asset Ratio (DAR), Total Asset Turnover (TATO), dan Inflasi terhadap Return On Asset (ROA) tidak menemukan pengaruh secara parsial Current Ratio (CR) terhadap Return On Asset (ROA) dan inflasi secara parsial juga tidak berpengaruh terhadap Return On Asset (ROA). Current Ratio (CR), Debt to Equity Ratio (DER), total asset turnover, dan inflasi secara bersama-sama berpengaruh terhadap Return On Asset (ROA). Sama dengan penelitian Dede Solihin (2019) yang berjudul prngaruh Current Ratio (CR) dan Debt to Equity Ratio (DER) terhadap Return On Asset (ROA) dengan hasil penelitian bahwa Current Ratio (CR) tidak memiliki pengaruh secara parsial terhadap Return On Asset (ROA). Sedangkan berdasarkan pengujian simultan CR dan DER terdapat pengaruh terhadap ROA. Kemudian pada penelitian Rika Hafsoh Laela, Hendratno (2019) secara parsial juga tidak menemukan pengaruh signifikan Current Ratio (CR) terhadap Return On Asset (ROA).

\section{METODE PENELITIAN}

Jenis penelitian yang dilakukan dalam penelitian ini merupakan jenis penelitian kuantitatif. Menurut Sugiyono (2017) menyatakan bahwa "metode penelitian kuantitatif dapat diartikan sebagai metode penelitian yang berlandaskan pada filsafat positivisme, digunakan untuk meneliti pada populasi atau sampel tertentu, pengumpulan data menggunakan instrumen penelitian, analisis data bersifat kuantitatif/statistic, dengan tujuan untuk menguji hipotesis yang telah ditetapkan”. Dimana penelitian ini mengumpulkan, menganalisis, menghitung jumlah dari data laporan keuangan pada PT. Selamat Sempurna Tbk Periode 2010-2019.

Jenis penelitian yang dilakukan oleh penulis merupakan penelitian yang bersifat deskriptif asosiatif. Menurut Sugiyono (2017) mengemukakan bahwa "deskriptif adalah suatu rumusan masalah yang berkenaan dengan pernyataan terhadap keberadaan variabel mandiri, baik hanya pada satu variabel atau lebih (variabel yang berdiri sendiri)". Jadi dalam penelitian ini penelitian tidak membuat perbandingan variabel itu pada sampel yang lain, dan mencari hubungan variabel itu dengan variabel yang lain. Selanjutnya menurut Sugiyono (2017) "asosiatif adalah suatu rumusan masalah penelitian 
yang bersifat menanyakan hubungan antara dua variabel atau lebih. Terdapat tiga bentuk hubungan yaitu: hubungan simetris adalah suatu hubungan antara dua variabel atau lebih yang kebetulan munculnya bersama, hubungan kausal adalah hubungan yang bersifat sebab akibat, dan interaktif/resiprokal/timbal balik adalah hubungan yang saling mempengaruhi”. Penelitian ini melakukan pembahasan atas permasalahan yang dihadapi oleh perusahaan terhadap kinerja keuangannya. Tujuan dari penelitian ini yaitu untuk membuat gambaran secara sistematis, faktual, dan akurat mengenai fakta-fakta yang terjadi.

Penelitian ini akan dilakukan pada perusahaan PT. Selamat Sempurna Tbk yang beralamat di Wisma ADR, Jl. Peluit Raya I No.1, Jakarta 14440, Indonesia Telepon (021) 6610039. Proses ini mencakup keseluruhan kerja mulai dari penetapan judul hingga pada proses hasil penelitian. Waktu penelitian ini dilakukan dari bulan Oktober 2020. Data-data yang diambil adalah laporan keuangan PT. Selamat Sempurna Tbk Periode 2010-2019.

Menurut Sugiyono (2015) "Variabel penelitian merupakan segala sesuatu yang berbentuk apa saja yang ditetapkan oleh peneliti untuk peneliti dipelajari sehingga diperoleh informasi tentang hal tersebut, kemudian ditarik kesimpulannya". Pada penelitian ini terdapat 3 variabel yang digunakan yaitu terdiri dari 2 variabel independen (bebas) dan 1 variabel dependen (terikat). Menurut Sugiyono (2011) "Variabel independent merupakan variabel yang dapat mempengaruhi variabel lain. Variabel ini sering disebut dengan variabel stimulus, predictor, entecedent. Dalam bahasa Indonesia sering disebut dengan variabel bebas. Variabel bebas merupakan variabel yang mempengaruhi atau yang menjadi sebab perubahannya atau timbulnya variabel dependen (terikat)".

\section{HASIL DAN PEMBAHASAN}

Analisis statistik deskriptif adalah statistik yang digunakan untuk memberikan gambaran terhadap suatu data sebagaimana adanya tanpa bermaksud membuat kesimpulan yang berlaku untuk umum atau generalisasi. Pengukuran yang digunakan dalam analisis statistik deskriptif pada penelitian ini menggunakan nilai minimum, rata-rata, maksimum dan standar deviasi.

Tabel 2.

Hasil Analisis Statistik Deskriptif

\section{Descriptive Statistics}

\begin{tabular}{cccccc}
\hline & N & Minimum & Maximum & Mean & Std. Deviation \\
\hline CR & 10 & 194.42 & 463.65 & 286.1660 & 93.03587 \\
DER & 10 & 27.22 & 96.01 & 55.0720 & 22.39304 \\
ROA & 10 & 14.10 & 24.03 & 20.4890 & 2.81755 \\
Valid N (listwise) & 10 & & & & \\
& & & & & \\
\hline
\end{tabular}

Sumber: OutputSPSS Versi 25,2021

Dengan melakukan perhitungan statistik deskriptif, maka dapat diketahui gambaran setiap masing-masing variabel yang bertujuan untuk mengetahui pengaruh Current Ratio (CR) dan Debt to Equity Ratio (DER) terhadap Return On Asset (ROA). Analisis ini hanya berupa akumulasi data dasar dalam bentuk deskripsi semata dalam arti tidak mencari atau menerangkan saling hubungan, men guji hipotesis, membuat ramalan, atau melakukan penarikan kesimpulan.

Pengaruh CR dan DER Terhadap ROA Pada PT. Selamat Sempurna TbkPeriode 2010-2019, Sella Putri Anisa dan Aria Aji Priyanto 
Uji normalitas merupakan pengujian asumsi klasik yang berdistribusi normal. Uji normalitas memiliki tujuan untuk menguji apakah model regresi variabel independen dan variabel dependen atau keduanya berdistribusi normal atau tidak.

Menurut Sugiyono (2017) "uji normalitas digunakan untuk mengkaji kenormalan variabel yang diteliti apakah data tersebut berdistribusi normal atau tidak". Hal tersebut sangat penting karena apabila data setiap variabel tidak normal, maka pengujian hipotesis tidak bisa dilanjutkan.

Berdasarkan hasil uji normalitas dengan menggunakan One-Sample Kolmogorov-Smirnov, suatu data dikatakan berdistribusi normal apabila Asymp. Sig. (2-tailed) pada output pengujian data tersebut menunjukan nilai $>0,05$ dan hasil dari olah data pada penelitian ini menunjukan nilai 0,200 maka dapat disimpulkan bahwa asumsi data berdistribusi normal.

Berikut ini merupakan hasil uji normalitas K-S dari perhitungan IBM SPSS versi 25 dapat dilihat sebagai berikut:

Tabel 3.

Hasil Uji Normalitas K-S

One-Sample Kolmogorov-Smirnov Test

\begin{tabular}{llr}
\hline & & Unstandardized Residual \\
\hline $\mathrm{N}$ NormalParameters & & 10 \\
& & 0.0000000 \\
Most ExtremeDifferences & Mean & 0.00728688 \\
& Std. Deviation & 0.117 \\
& Absolute & 0.114 \\
Test Statistic & Positive & -0.117 \\
Asymp.Sig. (2-tailed) & Negative & 0.117 \\
\hline Sumber: OutputSPSS Versi 25 & & $.200^{\mathrm{c}, \mathrm{d}}$ \\
\hline
\end{tabular}

Salah satu cara untuk mendeteksi ada atau tidak adanya masalah multikolinearitas dengan cara melihat nilai tolerance dan nilai variance inflation factor (VIF). Dalam kebanyakan penelitian menyebutkan bahwa jika tolerance $>0,10$ dan VIF $<10$, maka tidak terjadi multikolinearitas.

Tabel 4.

Hasil Uji Multikolinearitas

Dari hasil data diatas dapat diketahui bahwa nilai Tolerance dan VIF dari masing-masing variabel adalah dengan rincian, bahwa Current Ratio (CR) dan Deb to Equity Ratio (DER), masingmasing memiliki nilai Tolerance sebesar 0,334 dan nilai VIF sebesar 2,993. Data tersebut menunjukan bahwa nilai Tolerance $>0,10$ dan VIF $<10$. Maka dapat disimpulkan bahwa kedua variabel independen tersebut tidak terjadi gejala multikolinearitas pada variabel bebas dalam model regresi.

Coefficients $^{\mathrm{a}}$

\begin{tabular}{llcc}
\hline & & \multicolumn{2}{c}{ Collinearity Statistics } \\
\cline { 3 - 4 } Model & Tolerance & VIF \\
\hline 1 & (Constant) & & \\
& CR & 0.334 & 2.993 \\
& DER & 0.334 & 2.993 \\
\hline
\end{tabular}

Sumber: OutputSPSS Versi 20,2021

Pengaruh CR dan DER Terhadap ROA Pada PT. Selamat Sempurna Tbk Periode 2010-2019, Sella Putri Anisa dan Aria Aji Priyanto 


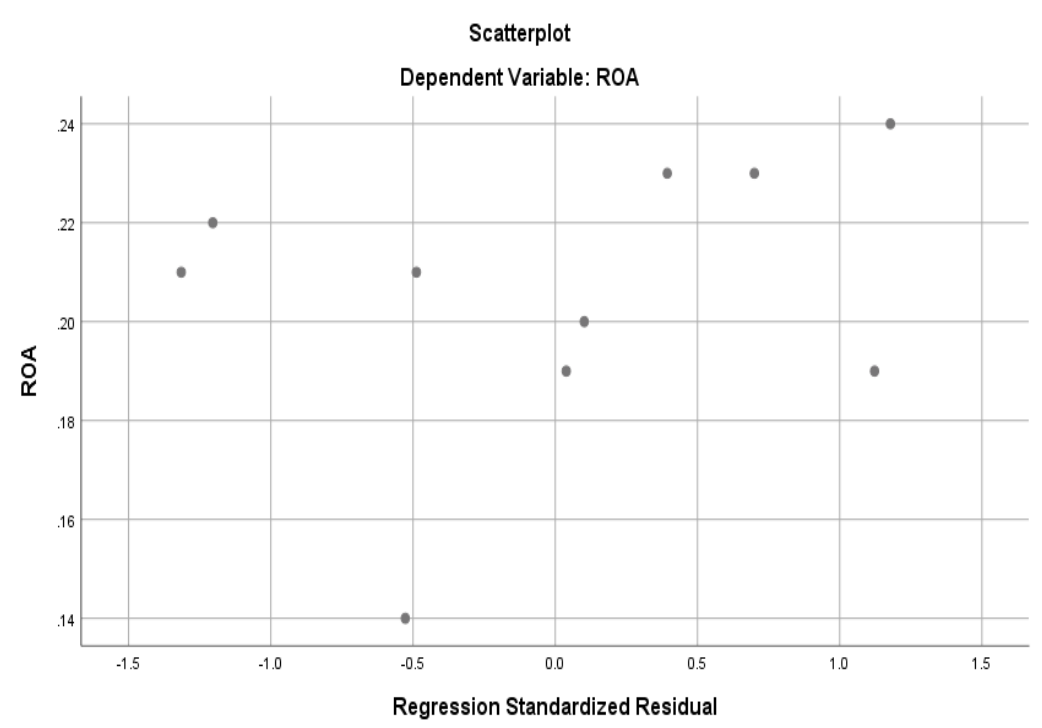

Sumber: Output SPSS Versi 25,2021

Gambar 1.

Hasil Uji Heteroskedastisitas

Berdasarkan gambar diatas diketahui bahwa titik-titik menyebar dengan pola secara acak dan tidak membentuk pada pola tertentu. Jadi, dapat disimpulkan bahwa model regresi yang digunakan tidak terdapat adanya heteroskedastisitas.

Uji Autokorelasi bertujuan untuk melihat apakah ada tidaknya autokorelasi dalam suatu model regresi. Jika terjadi korelasi maka dinamakan ada problem autokorelasi. Model regresi yang baik adalah yang bebas dari autokorelasi. Model regresi dinyatakan bebas autokorelasi jika harg a DW memenuhi kriteria DU<DW<4-DU (Ghozali, 2016).

Tabel 5.

Hasil Uji Autokorelasi Durbin Watson

Model Summary

\begin{tabular}{|c|c|c|c|c|c|}
\hline Model & $\mathbf{R}$ & R Square & $\begin{array}{l}\text { Adjusted R } \\
\text { Square }\end{array}$ & $\begin{array}{l}\text { Std. Error of the } \\
\text { Estimate }\end{array}$ & $\begin{array}{l}\text { Durbin- } \\
\text { Watson }\end{array}$ \\
\hline 1 & $.967^{\mathrm{a}}$ & 0.936 & 0.917 & 0.00826 & 2.255 \\
\hline
\end{tabular}

Berdasarkan tabel tersebut diketahui bahwa nilai Durbin Watson sebesar 2,255 yang artinya pada rumus $\mathrm{DU}<\mathrm{DW}<4$-DU maka $1,6413<2,255<2,3857$. Perbandingan menggunakan nilai signifikan 5\%, jumlah sampel $10(\mathrm{n})$, dan jumlah variabel independent $2(\mathrm{k}=2)$, maka di tabel Durbin Watson akan di dapat nilai du sebesar 1,6413. Karena nilai DW 2,255 lebih besar dari batas atas du 1,6413 dan kurang dari 4-(1,6413) = 2,3587, maka dapat disimpulkan bahwa tidak terdapat autokorelasi pada data yang digunakan pada penelitian ini.

Dari persamaan diatas dapat diketahui nilai konstanta sebesar 0,172 artinya jika nilai Current Ratio (CR) adalah 0 maka nilai Return On Asset (ROA) adalah 0,172. Dan koefisien regresi current Ratio (CR) sebesar 0,012 artinya bahwa setiap kenaikan 1\% tingkat Current Ratio (CR) maka Return On Asset (ROA) akan meningkat sebesar 0,012. Karena nilainya positif maka dengan demikian dapat dikatakan Current Ratio (CR) berpengaruh positif terhadap Return On Asset (ROA). 
Tabel 6.

Hasil Uji Linier Sederhana(CR Terhadap ROA)

Coefficients $^{\mathrm{a}}$

\begin{tabular}{|c|c|c|c|c|c|}
\hline \multirow[b]{2}{*}{ Model } & \multicolumn{2}{|c|}{ Unstandardized Coefficients } & \multirow{2}{*}{$\begin{array}{c}\begin{array}{c}\text { Standardized } \\
\text { Coefficients }\end{array} \\
\text { Beta }\end{array}$} & \multirow[b]{2}{*}{$\mathbf{t}$} & \multirow[b]{2}{*}{ Sig. } \\
\hline & B & Std. Error & & & \\
\hline $1 \quad$ (Constant) & 0.172 & 0.030 & & 5.703 & 0.000 \\
\hline $\mathrm{CR}$ & 0.012 & 0.010 & 0.389 & 1.195 & 0.266 \\
\hline
\end{tabular}

Sumber: OutputSPSS Versi, 2021

Dari persamaan diatas dapat diketahui nilai konstanta sebesar 0,265 artinya jika nilai Debt to Equity Ratio (DER) adalah 0 maka nilai Return On Asset (ROA) sebesar 0,106 artinya bahwa setiap kenaikan 1\% tingkat Debt to Equity Ratio (DER) maka Return On Asset (ROA) akan meningkat sebesar 0,106. Karena nilainya positif maka dengan demikian dapat dikatakan dapat dikatakan Debt to Equity Ratio (DER) berpengaruh positif terhadap Return On Asset (ROA). Berikut adalah hasil data pengaruh Debt to Equity Ratio (X2) terhadap Return On Asset (Y):

Tabel 7.

Hasil Uji Linier Sederhana(DER terhadap ROA)

Coefficients $^{\mathrm{a}}$

\begin{tabular}{|c|c|c|c|c|c|}
\hline \multirow[b]{2}{*}{ Model } & \multicolumn{2}{|c|}{ Unstandardized Coefficients } & \multirow{2}{*}{$\begin{array}{c}\begin{array}{c}\text { Standardized } \\
\text { Coefficients }\end{array} \\
\text { Beta }\end{array}$} & \multirow[b]{2}{*}{$\mathbf{t}$} & \multirow[b]{2}{*}{ Sig. } \\
\hline & $\mathbf{B}$ & Std. Error & & & \\
\hline $1 \quad$ (Constant) & 0.265 & 0.015 & & 17.696 & 0.000 \\
\hline DER & -0.106 & 0.025 & -0.830 & -4.201 & 0.003 \\
\hline
\end{tabular}

Sumber: OutputSPSS Versi, 2021

Tabel 8.

Hasil Uji Regresi Linier Berganda

Coefficients $^{\mathrm{a}}$

\begin{tabular}{|c|c|c|c|c|c|}
\hline \multirow[b]{2}{*}{ Model } & \multicolumn{2}{|c|}{ Unstandardized Coefficients } & \multirow{2}{*}{$\begin{array}{l}\text { Standardized } \\
\text { Coefficients } \\
\text { Beta } \\
\end{array}$} & \multirow[b]{2}{*}{$\mathbf{t}$} & \multirow{3}{*}{$\frac{\text { Sig. }}{0.000}$} \\
\hline & B & Std. Error & & & \\
\hline (Constant) & 0.390 & 0.025 & & 15.456 & \\
\hline $\mathrm{CR}$ & -0.027 & 0.005 & -0.861 & -5.195 & 0.001 \\
\hline DER & -0.196 & 0.021 & -1.532 & -9.245 & 0.000 \\
\hline
\end{tabular}

Sumber: Output SPSS Versi 25

Persamaan linier berganda diatas mempunyai interprestasi yaitu konstanta (a) sebesar 0,390 menunjukan bahwa jika perubahan variabel Current Ratio (CR) dan Debt to Equity Ratio (DER) konstanta bernilai 0 , maka nilai ROA adalah 0,390. Variabel CR $\left(\mathrm{X}_{1}\right)$ mempunyai koefisien regresi 
bernilai negatif -0,027. Hal ini menunjukkan bahwa setiap penambahan satu kali CR maka ROA (Y) akan mengalami kenaikan sebesar -0,027. Koefisien bernilai negatif artinya terjadi hubung an negatif antara CR dengan ROA, semakin naik CR maka semakin naik pula ROA. Variabel DER sebesar 0,196 dan bertanda negatif, artinya adalah jika variabel independen lain nilainya tetap dan DER mengalami kenaikan 1 kali, maka ROA (Y) akan mengalami penurunan ssebesar -0,196. Koefisien bernilai negatif artinya terjadi hubungan negatif antara DER dengan ROA, semakin naik DER maka ROA semakin menurun.

Tabel 9.

Hasil Uji Koefisien Determinasi

\begin{tabular}{|c|c|c|c|c|c|}
\hline \multicolumn{6}{|c|}{ Model Summary ${ }^{\mathbf{b}}$} \\
\hline Model & $\mathbf{R}$ & R Square & $\begin{array}{l}\text { Adjusted } \\
\text { Square }\end{array}$ & & $\begin{array}{l}\text { Std. Error of the } \\
\text { Estimate }\end{array}$ \\
\hline 1 & $.967^{\mathrm{a}}$ & 0.936 & 0.917 & & 0.00826 \\
\hline
\end{tabular}

Sumber: OutputSPSS Versi 25,2021

Berdasarkan tabel tersebut besarnya pengaruh variabel ditujukan oleh Adjusted $\mathrm{R}^{2}=0,917$ maka $\left(\mathrm{KD}=\mathrm{r}^{2} \times 100 \%=0,917 \times 100 \%=91,7 \%\right)$ jadi dapat disimpulkan bahwa Current Ratio $(\mathrm{CR})$ dan Debt to Equity Ratio (DER) berpengaruh 91,7\% terhadap Return On Asset (ROA), sedangkan sisanya $8,3 \%$ dipengaruhi oleh variabel lain yang tidak diteliti di dalam penelitian ini.

Tabel 10.

Hasil Uji Parsial (Uji t)

Coefficients $^{\mathbf{a}}$

\begin{tabular}{|c|c|c|c|c|c|}
\hline \multirow[b]{2}{*}{ Model } & \multicolumn{2}{|c|}{ Unstandardized Coefficients } & \multirow{2}{*}{$\begin{array}{l}\text { Standardized } \\
\text { Coefficients } \\
\text { Beta } \\
\end{array}$} & \multirow[b]{2}{*}{$\mathbf{t}$} & \multirow{3}{*}{$\frac{\text { Sig. }}{0.000}$} \\
\hline & B & Std. Error & & & \\
\hline (Constant) & 0.390 & 0.025 & & 15.456 & \\
\hline $\mathrm{CR}$ & -0.027 & 0.005 & -0.861 & -5.195 & 0.001 \\
\hline DER & -0.196 & 0.021 & -1.532 & -9.245 & 0.000 \\
\hline
\end{tabular}

Sumber: OutputSPSS Versi 25,2021

Variabel CR $\left(\mathrm{X}_{1}\right)$ diatas diperoleh nilai $\mathrm{t}_{\text {hitung }}$ sebesar $-5,195$, sedangkan $\mathrm{t}_{\text {tabel }}$ dengan tingkat signifikan 5\% $(0,05)$ dan derajat kebebasan $(\mathrm{dk})=\mathrm{n}-\mathrm{k}-1=10-2-1=7$ adalah sebesar 2,365. Dengan melakukan perbandingan yaitu $t_{h i t u n g}(-5,195)>t_{\text {tabel }}(2,364)$ maka $\mathrm{H}_{0}$ ditolak dan $\mathrm{H}_{\mathrm{a}}$ diterima. Nilai signifikan sebesar 0,001 dimana nilai $0,001<0,05$ maka $\mathrm{H}_{0}$ ditolak dan $\mathrm{H}_{\mathrm{a}}$ diterima, yang artinya koefisian variabel CR $\left(\mathrm{X}_{1}\right)$ secara parsial signifikan mempengaruhi variabel ROA $(\mathrm{Y})$.

Variabel DER $\left(X_{2}\right)$ diatas diperoleh nilai $t_{h i t u n g}$ sebesar $-9,245$ sedangkan $t_{\text {tabel }}$ dengan tingkat signifikan 5\% dan derajat kebebasan $(\mathrm{dk})=\mathrm{n}-\mathrm{k}-1=10-2-1=7$ adalah sebesar 2,365. Dengan melakukan perbandingan yaitu $\mathrm{t}_{\text {hitung }}(-9,245)>\mathrm{t}_{\text {tabel }}(2,364)$ maka $\mathrm{H}_{0}$ ditolak dan $\mathrm{H}_{\mathrm{a}}$ diterima. Nilai signifikan sebesar 0,000 dimana nilai $0,000<0,05$ maka $\mathrm{H}_{0}$ ditolak dan $\mathrm{H}_{\mathrm{a}}$ diterima, yang artinya koefisien variabel DER $\left(\mathrm{X}_{2}\right)$ secara parsial terdapat pengaruh signifikan terhadap variabel ROA $(\mathrm{Y})$.

Dari tabel ANOVA (Analysis of Varians) atau uji F, menunjukan bahwa $\mathrm{F}_{\text {hitung }}$ sebesar 50,990 dengan nilai signifikan sebesar 0,000. Sedangkan untuk mencari $F_{\text {tabel }}$ dengan jumlah sampel $(n)=10$; jumlah variabel bebas $(\mathrm{k})=2$; taraf signifikan $\alpha=5 \%(0,05)$ untuk mencari $\mathrm{F}_{\text {tabel }}$ yaitu dengan $(\mathrm{k} ; \mathrm{n}-$ $\mathrm{k})=2 ; 10-2=8$ diperoleh nilai $\mathrm{F}_{\text {tabel }}=4,46$ sehingga $\mathrm{F}_{\text {hitung }} 50,990>\mathrm{F}_{\text {tabel }} 4,46$ dan secara sistematik diperoleh nilai signifikan 0,000 . karena nilai signifikan $0,000<$ taraf signifikan 0,05 dengan demikian 
$\mathrm{H}_{0} 3$ ditolak dan $\mathrm{H}_{\mathrm{a}} 3$ diterima. Hal ini menunjukan bahwa Current Ratio (CR) dan Debt to Equity Ratio (DER) secara simultan berpengaruh signifikan terhadap Return On Asset (ROA).

Tabel 11.

Hasil Uji Simultan (Uji F)

ANOVA $^{\mathrm{a}}$

\begin{tabular}{|c|c|c|c|c|c|}
\hline Model & Sum of Squares & df & MeanSquare & $\mathbf{F}$ & Sig. \\
\hline Regression & 0.007 & 2 & 0.003 & 50.990 & $.000^{\mathrm{b}}$ \\
\hline Residual & 0.000 & 7 & 0.000 & & \\
\hline Total & 0.007 & 9 & & & \\
\hline
\end{tabular}

Sumber: Output SPSS versi 25 (2021)

Berdasarkan hasil penelitian diatas yang menguji pengaruh Current Ratio (CR) dan Debt to Equity Ratio (DER) terhadap Return On Asset (ROA), maka ada beberapa hal yang dapat dibahas dan dijelaskan dalam penelitian ini, yaitu pengaruh Current Ratio (CR) Terhadap Return On Asset (ROA) pada PT. Selamat Sempurna Tbk Periode 2010-2019. Berdasarkan hasil penelitian variabel Current Ratio (CR) pada uji regresi linear sederhana diketahui memiliki nilai konstanta sebesar 0,172 artiny a jika nilai Current Ratio (CR) adalah 0 maka Return On Asset (ROA) adalah 0,172. Dan koefisien regresi Current Ratio (CR) sebesar 0,012 artinya bahwa setiap kenaikan 1\% tingkat Current Ratio (CR) maka Return On Asset (ROA) akan meningkat sebesar 0,012. Karena nilainya positif maka dengan demikian dapat dikatakan Current Ratio (CR) berpengaruh positif terhadap Return On Asset (ROA). Pada uji parsial (uji t) memiliki nilai thitung $>t_{\text {tabel }}$ yaitu sebesar $-5,195>2,364$ dan signifikan sebesar $0,001<0,05$. Hal ini $\mathrm{H}_{0} 1$ ditolak dan $\mathrm{H}_{\mathrm{a}} 1$ diterima sehingga dapat dikatakan bahwa Current Ratio (CR) secara parsial berpengaruh signifikan terhadap Return On Asset (ROA) pada PT. Selamat Sempurna Tbk periode 2010-2019. Dengan current ratio yang tinggi perusahaan mampu membayar hutang jangka pendek secara tepat waktu sehingga operasional berjalan lancar, operasional yang berjalan lancar akan meningkatkan penjualan, penjualan yang meningkat akan menghasilkan laba atau keuntungan yang besar dan berhasil memanfaatkan asset yang ada untuk menghasilkannya. Hal ini sejalan dengan penelitian Setiawan \& Chyono (2019), Apriyanti (2019), Dewi, dkk (2015), dan Darmawan \& Nurochman (2016) yang menyatakan bahwa Current Ratio (CR) menunjukan secara parsial berpengaruh terhadap Return On Asset (ROA).

Pengaruh Debt to Equity Ratio (DER) Terhadap Return On Asset (ROA) pada PT. Selamat Sempurna Tbk Periode 2010-2019. Berdasarkan hasil penelitian variabel Debt to Equity Ratio (DER) pada uji regresi linier sederhana diketahui nilai konstanta sebesar 0,265 artinya jika nilai Debt to Equity Ratio (DER) adalah 0 maka nilai Return On Asset (ROA) adalah 0,265. Dan koefisien regresi Debt to Equity Ratio (DER) sebesar -0,106 artinya bahwa setiap kenaikan 1\% tingkat Debt to Equity Ratio (DER) maka Return On Asset (ROA) akan meningkat sebesar -0,106. Karena nilainya negatif maka dengan demikian dapat dikatakan Debt to Equity Ratio (DER) berpengaruh negatif terhadap Return On Asset (ROA). Pada uji parsial (uji t) memiliki thitung $>t_{\text {tabel }}$ yaitu sebesar -9,245 $>2,364$ dan signifikan sebesar $0,000<0,05$. Hal ini berati $\mathrm{H}_{0} 2$ ditolak dan $\mathrm{H}_{\mathrm{a}} 2$ diterima sehingga dapat dikatakan bahwa Debt to Equity Ratio (DER) secara parsial berpengaruh signifikan terhadap Return On Asset (ROA). Dengan debt to equity ratio yang rendah perusahaan mampu melunasi semua hutang jangka pendek maupun jangka panjang sehingga semakin kecil juga resiko yang ditanggung oleh perusahaan, besar kecilnya hutang yang ditanggung dapat mempengaruhi jumlah laba yang diperoleh peru sahaan, dengan total hutang yang kecil maka laba yang dihasilkan perusahaan akan besar. Hal ini sejalan

Pengaruh CR dan DER Terhadap ROA Pada PT. Selamat Sempurna Tbk Periode 2010-2019, Sella Putri Anisa dan Aria Aji Priyanto 
dengan penelitian Dewi, dkk (2015), Apriyanti (2019), dan Wanny, dkk (2019) yang menyatakan bahwa Debt to Equity Ratio (DER) terdapat pengaruh signifikan.

Pengaruh Current Ratio (CR) dan Debt to Equity Ratio (DER) Terhadap Return On Asset (ROA) pada PT. Selamat Sempurna Tbk Periode 2010-2019. Berdasarkan hasil penelitian variabel Current Ratio (CR) dan Debt to Equity Ratio (DER) pada uji regresi linier berganda diketauhi nilai konstanta sebesar 0,390 artinya jika nilai Current Ratio (CR) dan Debt to Equity Ratio (DER) adalah 0 maka nilai Return On Asset (ROA) adalah 0,390. Pada koefisien regresi Current Ratio (CR) -0,027 artinya adalah jika variabel independen lain nilainya tetap dan Current Ratio (CR) mengalami perubahan 1 kali maka Return On Asset (ROA) akan mengalami kenaikan sebesar -0,027. Koefisien bernilai negatif artinya terjadi hubungan negatif antara Current Ratio (CR) dengan Return On Assset (ROA) dan pada variabel Debt to Equity Ratio (DER) sebesar -0,196 dan bertanda negatif, artinya adalah jika variabel independen lain nilainya tetap dan Debt to Equity Ratio (DER) mengalami kenaikan 1 kali, maka Return On Asset (ROA) akan mengalami penurunan sebesar 0,196. Koefisien bernilai negatif artinya terjadi hubungan negatif antara Debt to Equity Ratio (DER) dengan Return On Asset (ROA). Pada uji simultan (uji F) memiliki $F_{\text {hitung }}$ dan $F_{\text {tabel }}$ sebesar 50,990 > 4,74 dan secara sistematik diperoleh nilai signifikan 0,000. Karena nilai signifikan $0,000<0,05$, dengan demikian $\mathrm{H}_{0} 3$ ditolak dan $\mathrm{H}_{\mathrm{a}} 3$ diterima. Dengan nilai return on asset yang tinggi maka akan semakin tinggi pula laba bersih yang dihasilkan disetiap rupiah yang tertanam dalam total asset, sehingga perusahaan telah efisien dalam menggunakan aktivanya dalam kegiatan operasional, kegiatan operasional yang berjalan lancar maka akan menghasilkan keuntungan yang besar dan berhasil memanfaatkan asset yang ada. Hal ini menunjukan bahwa Current Ratio (CR) dan Debt to Equity Ratio (DER) secara simultan berpengarauh signifikan terhadap Return On Asset (ROA).

\section{SIMPULAN DAN SARAN}

Berdasarkan uji parsial (uji t) variabel Current Ratio $\left(\mathrm{X}_{1}\right)$ secara parsial berpengaruh signifikan terhadap variabel Return On Asset $(\mathrm{Y})$. Variabel Debt to Equity Ratio $\left(\mathrm{X}_{2}\right)$ secara parsial berpengaruh signifikan terhadap variabel Return On Asset (Y). Berdasarkan uji simultan (uji F) menunjukan bahwa Current Ratio $\left(\mathrm{X}_{1}\right)$ dan Debt to Equity Ratio $\left(\mathrm{X}_{2}\right)$ secara simultan berpengaruh signifikan terhadap Return On Asset (Y). Berdasarkan uji determinasi, dapat disimpulkan bahwa Current Ratio (CR) dan Debt to Equity Ratio (DER) bepengaruh sebesar 91,7\% terhadap Return On Asset (ROA), sedangkan sisanya $8,3 \%$ dipengaruhi oleh variabel lain yang tidak diteliti di dalam penelitian ini.

Dari hasil kesimpulan dalam penelitian ini, maka saran yang dapat diberikan bagi manajemen PT. Selamat Sempurna Tbk diharapkan mampu dalam meningkatkan Return On Asset perusahaan, kepada pihak manajemen harus memperhitungkan komposisi Current Ratio dan Debt to Equity Ratio. Karena jika kedua rasio keuangan tersebut dalam kondisi optimal, maka Return On Asset juga akan meningkat. Perusahaan harus menjaga keseimbangan kedua rasio tersebut dalam penentuan Return On Asset. Bagi para investor perusahaan yang bagus adalah perusahaan yang memiliki profitabilitas yang tinggi meskipun dengan memiliki Current Ratio yang rendah. Artinya perusahaan tersebut mampu menjalankan dengan efisien dan efektifitas dalam mengelola sumber daya. Kemudian dengan Debt to Equity Ratio yang rendah, perusahaan mampu menutupi semua kebutuhan modalnya dengan modal sendiri. Sehingga investor sebaiknya juga memperhatikan dari rasio-rasio tersebut, karena dari rasiorasio tersebut juga menunjukkan suatu kinerja perusahaan. Bagi peneliti selanjutnya diharapkan dapat

Pengaruh CR dan DER Terhadap ROA Pada PT. Selamat Sempurna Tbk Periode 2010-2019, Sella Putri Anisa dan Aria Aji Priyanto 
melakukan pengembangan lebih lanjut dari penelitian ini dengan menggunkan jumlah sampel yang lebih banyak dan sebaiknya juga menambahkan variabel independen lainnya.

\section{REFERENSI}

Apriyanti, Puput. 2017. Pengaruh Current Ratio (CR) dan Debt to Equity Ratio (DER) Terhadap Retu rn On Asset ( ROA) Pada PT Supreme Cable Manufakturing \& Commerce Tbk, Tahun 2006-2017 Program Studi Manajemen. Skripsi, Universitas Pamulang, Tanggerang Selatan.

Darmawan, Ahmad, and Alis Dwian Nurochman.2015. Pengaruh Current Ratio Dan Debt To Asset Ratio. Jurnal Studia Akuntansi Dan Bisnis 4(2),57-66.

Dewi, Ni Ka dek Venimas Citra, Wayan dan Cipta, a nd I. Ketut Kirya. 2015. PengaruhLDR, LAR, DER Dan CR Terhadap ROA. Journal Bisma Universitas Pendidikan Ganesha 3(1),1-10.

Ghazali, I. 2016. Aplikasi Analisis Multivariete Dengan Program IBM SPSS23 (Edisi 8). Se marang: B adan Penerbit Universitas Diponegoro.

Jenni, Jenni, La u Yeni, Merissa Merissa, Trisha Wanny, Erlin Erlin, and Isna Asdiani Na sution. 2019. "Penganuh TATO, DER Dan Current Ratio Terhadap ROA Pda Perusahaan Property Dan Real Esta te.” Owner 3(2), 127-139. doi: 10.33395/owner.v3i2.127.

Kasmir. 2014. Analisis Laporan Keuangan. Ja karta: PT. Raja Grafindo Persada.

La ela, Rika Hafsoh, and Hendratno. 2019. "Pengaruh Current Ratio, DebtTo Equity Ratio Da n Total Asset Turnover Terhadap Return on Asset Yang Terdaftar Di Bursa Efek Indonesia Periode 2013-2017.” Jurnal Akuntansi, AuditDan Sistem Informasi Akuntansi. 3(1),120-31.

Priyanto, Aria Aji. 2019. "Faktor-Faktor Yang Mempengaruhi Return On Asset (ROA) Pada PT. In docement Tunggal Prakarsa Tbk Tahun 2007-2017." Jurnal Ilmu Manajemen.2(1), 1-16.

Setiawan, Andi, and Krido Eko Cahyono. 2019. "Penga ruh Rasio Keuangan Der, Cr, Ta to Terhadap Roa Perusa haan Makanan Dan Minuman." Jurnal EKSEKUTIF 16(2),379-98.

Solihin, Dede. 2019. "Pengaruh Current Ratio dan Debt to Equity Ratio Terhadap Return On Asset (ROA) Pa d a PT Kalbe Farma, Tbk." KREATIF : Jurnal Ilmiah Prodi Manajemen Universitas Pamulang 7(1),115-122. doi: 10.32493/jk.v7i1.y2019.p115-122.

Sugiyono. 2011. Metode Penelitian Kuantitatif Kualitatif Dan R\&D. Bandung: Alfabeta.

Sugiyono. 2015. Metode Penelitian Kombinasi (Mix Methods). Bandung: Alfabeta.

Sugiyono. 2017. Metode Penelitian Kuantitatif, Kualitatif Dan R\&D. Bandung: Alfabeta, cv.

Supardi, Herman, H. SuratnoH. Suratno, and Suyanto Suyanto. 201 8. "Pengaruh CurrentRatio, Debt To Asset Ratio, Total Asset Turnover Dan Inflasi Terhadap Return on Asset." JIA FE (Jurnal Ilmiah Akuntansi Fakultas Ekonomi) 2(2), 16-27. doi: 10.34204/jiafe.v2i2.541.

Wahyudi, Sugeng.2003. Pengaruh Rasio Harga Nilai Buku dan Rasio Hutang Modal Sendiri Terha dap Return Saham, Media Ekonomi dan Bisnis, 15(2), 1-22. 